\section{Volatile Fruit Flavours}

THE report of a symposium held in Berne during 1962, one of a series organized by the Scientific and Technical Commission of the International Federation of Fruit Juice Producers, summarizes the great advances made in the chemistry and technology of fruit aromas since tho advent of gas-liquid chromatography (Volatile Fruit Flavour's. Pp. 449. Zurich: Juris-Verlag, 1962. Obtainable from International Fruit Juice Union, Eschenz TG, Switzerland. $40 \mathrm{Sw}$. Fr.). The papers prosented, reviews or original papers, are in English, French or German with tri-lingual summaries. Of the 38 articles, 28 deal with tho chemistry of aroma components or with their commercial recovery from fruits and juicess. The devolopments so far have already led to significant improvements in the quality of juice products; the more detailed examination of aroma components is now beginning to make possible a more quantitative assessment of quality, though sensory tests still remain the final criteria.

\section{Investigations of Infra-red Spectra}

Dr. 1R. N. Jones, president of the Coblent\% Society, has written to the Editor saying that, with the permission of the Carnegic Institution of Washington, the Coblentz Society has arranged for the re-publication of the Carnegie Institution Monograph No. 35, Investigations of Infrared Spectra. In this is published the original research work of Dr. W. W. Coblentz, who first established the potentialities of infra-red spectroscopy as a tool in organic chemical research, and who died in Washington last september at the age of eighty-eight. The Monograph, which was originally published in 1905, has long been out of print; it is believed that it will be of interest to many molecular spectroscopists outside the immediate circle of the Society members. A limited number of copies are still available at a price of 3.5 dollars, and can be obtained from Dr. H. B. Kessler, secretary of tho Coblentz Society, the Perkin-Elmer Corporation, Norwalk, Connecticut.

The Coblentz Society was formed in 1954 with the view of bringing together physicists and chemists concerned with the development and application of infra-red spectroscopy and has its headquarters in the United States.

\section{The Sun during the International Geophysical Year}

Dr. M. A. Ellison, senior professor in tho School of Cosmic Physies at tho Dublin Institute for Advanced Studios and editor of Volumes 21 and 22 of the Annals of the International Geophysical Year (I.G.Y.Y. Solar Activity Maps, DI and DII), which were reviewed on p. 1237 of the September 29, 1962, issue of Nature, has written to the Editor of Nature as follows: "In the review . . thero was no mention of the greatly reduced price available to individuals who eertify that the Maps are for thoir own personal uso ( $£ 18$ as against $£ 54$ to Institutions). . . Such orders must be addrossed to IGY Solar Maps, Porgamon Pross, Headington Hill Hall, Oxford. England".

\section{Course in Nuclear Magnetic Resonance Techniques}

A sPECIAL advancod courso on "Nuclear Magnetic Resonance in Molecules of Moderate and High Molecular Weight" will be held during April 25-26. The speakers include Prof. A. R. Katritzky, and Drs. R. Froeman, D. W. Jonos, J. A. S. Smith and I. M. Ward. Applications in inorganic, organic and polymer chemistry will be considered, and there will be a short session on commercial equipmont. The fee for the course is $30 s$. Further details and registration forms can be obtained from the Registrar, Institute of Technology, Bradford 7.

\section{The Night Sky in April}

Futs moon occurs on April 9d. 00h. 57m. v.T. and new moon on April 23d. 20h. $29 \mathrm{~m}$. The following conjunetions with the Moon take place: April 3ct. 05h.. Mars 2 N. April 18d. 23h., Saturn l N.; April 21d. 09h., Vonus $3^{\circ} \mathrm{N}$. In addition to these conjunctions with the Moon. Venus is in conjunction with Jupiter on April 28d. 17h., Venus being $0.6^{\circ} \mathrm{s}$. Mercury is an evening star, and is conveniently placed for observation during the last week of the month, when it sets about two hours after the Sum. Venus is a morning star, rising about an hour before the Sun. Mars sets at $4 \mathrm{~h} .10 \mathrm{~m} . .3 \mathrm{~h} .20 \mathrm{~m}$. and $2 \mathrm{~h}$. $30 \mathrm{~m}$. on April 1, 15 and 30, respectively. It is at a distance of 101 million milos on April 15, when its stellar magnitude is +0.5 and it is in Cancer. Jupiter and Saturn are too close to the Sun for easy observation. There are no occultations of stars brighter than magnitude 6 visible at Greenwich. The Lyrid meteors are active during April 19-22, the radiant being at R.A. $18 \mathrm{~h} .04 \mathrm{~m} .$. Dec. $+33^{\circ}$; conditions for observation are favourable.

\section{Announcements}

Prof. Bernd 'T'. Matrhias, professor of physies at the University of California. San Diego, has been awarded the twenty-seventh Research Corporation Award for his outstanding contributions in the fields of supereonductivity and ferroelectrieity. The Award includes an honorarim of 10,000 dollars.

Av international starch conforence will be held in Detmold during April 24-26. Further information can be obtained from Wolfgang Kempf. Arbeitsgemeinschaft (retroideforschung E.V.. Detmold, Am Schiityenberg 9.

The 1963 Central Africun Scientific and Medical Congress will be held at the College of Further Education, Church Road, Lusaka, during August 26--30. Further information can be obtained from the Honorary Secretary, P.O. Box 844, Lusaka, Northern Rhodesia.

THe third European Mycological Congress will be held in Glasgow during August 31-September 7. The programme will include a symposium on "Gasteromycetes". Further information can be obtained from the Local Secretary, Third European Mycological Congress, Botany Department, the University, Glasgow, Seotland.

The British Institution of Radio Engineers and the Institution of Eloctrical Engineers are organizing a joint symposium on "Automatic Control", which will be held at the University of Birmingham on March 28. Further information can be obtained from Mr. (i. K. Steel, Department of Electrical Engineering, College of Advaneed Technology, Gosta Green, Birmingham 4.

THe Third International Meoting in Forensic Immunology, Medicine, Pathology and Toxicology will be held in London during April 16-24. Among the subjects to be discussed will be the problems in relation to: aviation; odontology; horse doping; stains by human tissues; drug addiction; psychiatry; industrial toxicology ; clinical toxicology; plant and animal poisons; poisoning by therapeutic substances; questioned documents. Further information can be obtained from the Secretariat. Third International Meeting in Forensic Immunology, Medicine, Pathology and Toxicology, 28 Portland Place. London, W.1.

A symposium on "Aspects of Chemical Change during the Processing and Storage of Foods", arranged by the" Nutrition Society (Scottish Group), will bo held in the Royal College of Science and Technology. Glasgow, on April 20. The programme will include: foodstuffs as unstable chemical systoms; catalytic destruction of vitamin $\mathrm{A}$ and earotene; chemical change in fish muscl. during storage; flavour changes in potatons; the environment for chemical change in dried and frozen foods. Further information can be obtained from Dr. D. G. Armstrong, Department of Agricultural Biochemistry. King's College, Neweastle upon Tyne 1. 